\title{
Biodiversity in managed forests: Impressions from Scandinavia
}

\author{
by Winifred Kessler $^{1}$ and Mike Fenger ${ }^{2}$
}

To two forest ecologists from western Canada, it appeared that the Swedes and Fins are excessively enamored with (dare we say?) the "charismatically challenged" members of the Earth's biota. This impression was formed during our participation in the conference on "Biodiversity in Managed Forests Concepts and Solutions" held May 28 to June 8, 1997, at the Swedish University of Agricultural Sciences near Uppsala, Sweden. This was the fourth in a series, with previous conferences held in Portland, Oregon (Kolm and Franklin 1996); Canberra, Australia (Norton 1995); and British Columbia (Kessler 1996). All four events addressed relationships of forestry to forest-dependent wildlife, with an emphasis on strategies and practices for conserving biological diversity in managed landscapes. The focus of the Uppsala conference was on the existing scientific knowledge about forest biodiversity and the patterns and processes that regulate it. Four Swedish organizations cooperated to organize and host the conference: National Board of Forestry, Skogforsk (Forestry Research Institute of Sweden), Swedish Biodiversity Centre, and Swedish University of Agricultural Sciences. The organizers desired to stimulate lively discussion of where the scientific community stands on this issue, and to share ideas and expertise for maintaining biodiversity in forests of the temperate zone.

The previous conferences featured such creatures as owls, bears, salmon, tigers, and arboreal marsupials. Although the Uppsala conference overall addressed a wide variety of taxa, there appeared to be - especially from the European nations and Russia - a bias toward the bryophytes and lichens, "polypores" or wood-rotting fungi, and saproxylic beetles. A wealth of information was provided on the abundance, distribution, and ecology of these groups in the context of forest management. This emphasis seemed unusual to us; in our part of the world the mammals, birds, anadromous fishes, and flowering plants receive the most attention, with scant interest exhibited for invertebrates and non-vascular plants. During the conference, we would not only learn a lot about these "less charismatic" species; we would develop a clear understanding of why they command so much attention and interest in Scandinavian forest management.

\section{Conference Overview and Plenary}

In all, 388 delegates from 38 nations attended the conference at Uppsala. New research results were emphasized in the conference, which consisted of morning plenary sessions, concurrent afternoon technical sessions, and continuous poster displays throughout 3 days of meetings. These events were followed by a three-day field excursion to view managed forests in Sweden, and a choice of optional post-conference excursions to Finland and Russian Karelia or to the Ural Mountains of Russia.

\footnotetext{
${ }^{1}$ Chair, Forestry Program, University of Northern British Columbia, 3333 University Way, Prince George, BC V2N 4Z9, email winifred@unbc.ca. ${ }^{2}$ Ministry of Environment, Lands, \& Parks, Victoria, BC.
}

Conference participants also had the option of traveling to Jonkoping, Sweden to participate in a Food and Agricultural Organization/ European Economic Community/ International Labour Organization (FAO/EEC/ILO) Joint Committee workshop entitled "Putting Multiple-use Forestry into Practice;" or of visiting Elmia Wood 97, the world's largest forestry trade fair.

The first plenary session was intended to develop the regional contexts for biodiversity conservation in the world's forests. Plenary speakers included Jan Fryk and Maria Norrfalk (Sweden), Daniel Simberloff(USA), Fred Bunnell (Canada), and Jerry Franklin (USA). Highlights included a special guest appearance by Carl Linneas (or a reasonable facsimile, anyway), and a stumning slide show of Sweden's
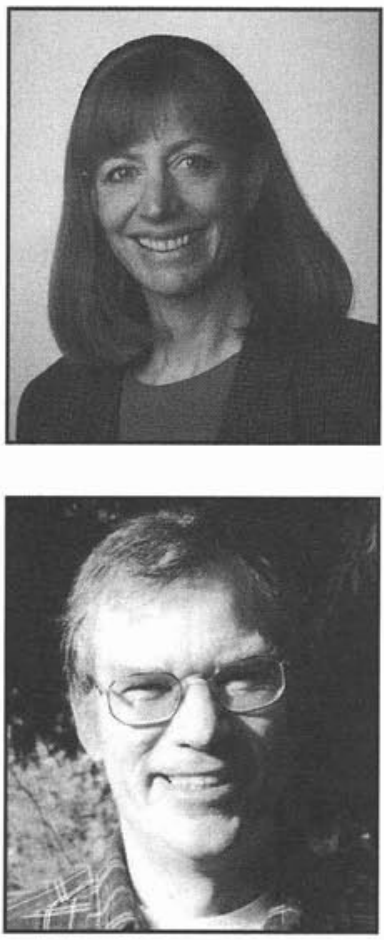
forests set to the music of Lars-Erik Larsson's Pasturalsvit.

The plenary on day two provided broad biodiversity comparisons in unmanaged and managed forests, including plantations. Speakers included George Peterken (United Kingdom), Jari Niemelä (Finland), and Winfried Bücking (Germany). The third plenary featured mapping, planning, monitoring, and other operational aspects of biodiversity assessment and conservation. A brief closing session was held on the final afternoon, with remarks provided by Sergey Ponomarenko (Russia), David Lindenmayer (Australia), and Thomas Rosswall (Sweden).

A special highlight on Saturday was the Gala Student Dinner, which provided opportunity to experience how Swedes celebrate the completion of their doctoral studies.

\section{The Scandinavian Context}

Sweden and Finland are well known for the efficiency of their forest management operations. That efficiency has been costly in terms of biological resources, however. About 1,500 forest species occur on Sweden's red-list of threatened species, including 739 invertebrates, 636 cryptograms, 59 vascular plants, and 53 vertebrates (Gustafsson 1996). Finland's list of threatened species includes 314 forest invertebrate species, the majority of which are associated with decaying wood (Kaila et al. 1994).

A variety of contemporary activities and conditions have modified-and continue to modify-forest landscapes in this part of the world. Such factors create the context for biodiversity conservation and forest management today; we would revisit 


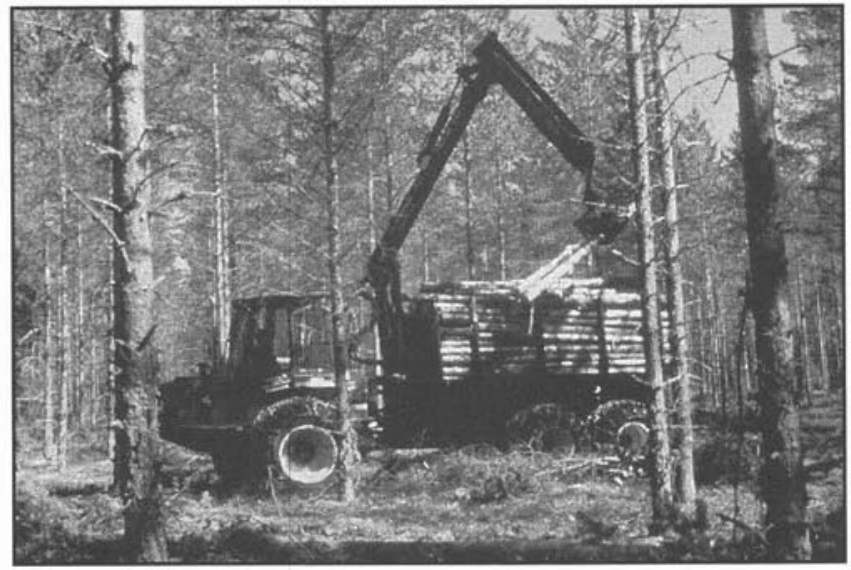

Fig. 1. Intensive and efficient management has been achieved at the cost of biological diversity in Swedish forest landscapes.

these factors often during the technical sessions and excursions. They included:

\section{Acid Rain}

The source is the industrial pollution that emanates from central Europe; the result is widespread damage to the aquatic fauna of lakes, rivers, and wetlands in northern Europe.

\section{Wetland Drainage}

Extensive drainage of wetlands, and conversion to agriculture and conifer plantations, has contributed to landscape homogeneity and to the direct loss of wetland communities.

\section{Pesticides}

Reductions in bird species diversity resulted from the use of agricultural pesticides before these practices were changed.

\section{Status of Protected Areas}

Sweden and Finland have few protected lands. Because of ownership patterns and political realities, there is little opportunity to establish a widespread system of ecological reserves.

\section{Homogeneous Management}

Modern forestry in Scandinavia consists of standardized, intensive methods aimed at maximizing the production of conifer products and the efficiency of forest operations. Deciduous trees, primarily birch and aspen, have been 1emoved from mixed stands in favour of pure conifer regeneration. The result is highly homogeneous landscapes dominated by even-age conifer stands of similar structure and composition.

\section{Absence of Natural Disturbance}

Because fire exclusion is nearly complete, Scandinavian landscapes have experienced losses in the diversity and abundance of fire-dependent species.

\section{Absence of Older Forests and Decaying Wood}

Managed on short rotations, forest stands do not attain oldgrowth structure. The near absence of woody debris in managed stands accounts for the low diversity of fungi, beetles, and other organisms that normally exist in association with rotting wood.

\section{Access}

The gentle topography and excellent road networks in Sweden and Finland make virtually all productive forests accessible to management. There are few rugged areas where protection is provided by virtue of poor access.

\section{Power Generation}

In a trend to eliminate nuclear power, Sweden is making increasing use of branches and tops that remain after forest harvesting.

\section{Land Ownerships Patterns}

In Sweden, only $5 \%$ of all forests are state-owned. Half the total occurs as 250,000 holdings distributed among 380,000 owners, with most of the remainder held by forest companies (National Board of Forestry 1996). In Finland, 24\% is state owned, $9 \%$ is owned by companies, and $62 \%$ occurs as private, nonindustrial forests (Finnish Forestry Association, undated). Given such patterns, planiing for biological diversity relies heavily on voluntary cooperation among landowners and others.

\section{Technical Sessions: State of the Science}

The technical sessions highlighted the problems that threaten biodiversity in boreal and other temperate-zone forests of the world. While emphasizing research findings, the sessions also encouraged management applications and practical solutions. The sessions were organized into five topic areas.

\section{Biodiversity - Historical Aspects}

This session provided the context for biodiversity conservation and forest management in northern Europe, a region having a very long history of human occupation. In Sweden, this history includes slash-and-burn agriculture spanning 2,000 years; extensive deforestation in the $1600 \mathrm{~s}$ and 1700 s associated with charcoal production for iron smelting; and an extensive rural population that used the forest for livestock grazing, hunting, fuelwood gathering, and other subsistence activities. Presentations from Finland, Denmark, and Belgium likewise revealed long and rich histories of people and forests. In this part of the world, it is of little value to speculate what the "pristine" forests may have been like. People have long lived in association with the land, and their activities have forever changed the patterns, processes, and biological diversity of the landscape.

\section{Examples from Different Continents}

This session illustrated how people in different parts of the world are incorporating objectives for biodiversity conservation into forest management strategies and practices. Included were examples from Bangladesh, Iran, and Australia in which biodiversity conservation objectives are being integrated into forest management strategies and policies. Other presentations examined past and current land use patterns use in India and Russia, including implications and challenges for biodiversity conservation.

\section{Impacts of Forestry on Biodiversity: Fauna}

Most of these speakers presented comparative data on the status of animal populations under different management forest regimes, including unmanaged forests. The cases included forest bird communities in Maine (USA), cavity-nesting birds in southern British Columbia, and wild ungulates in the Italian Alps. Other presentations focused on beetle species and communities 


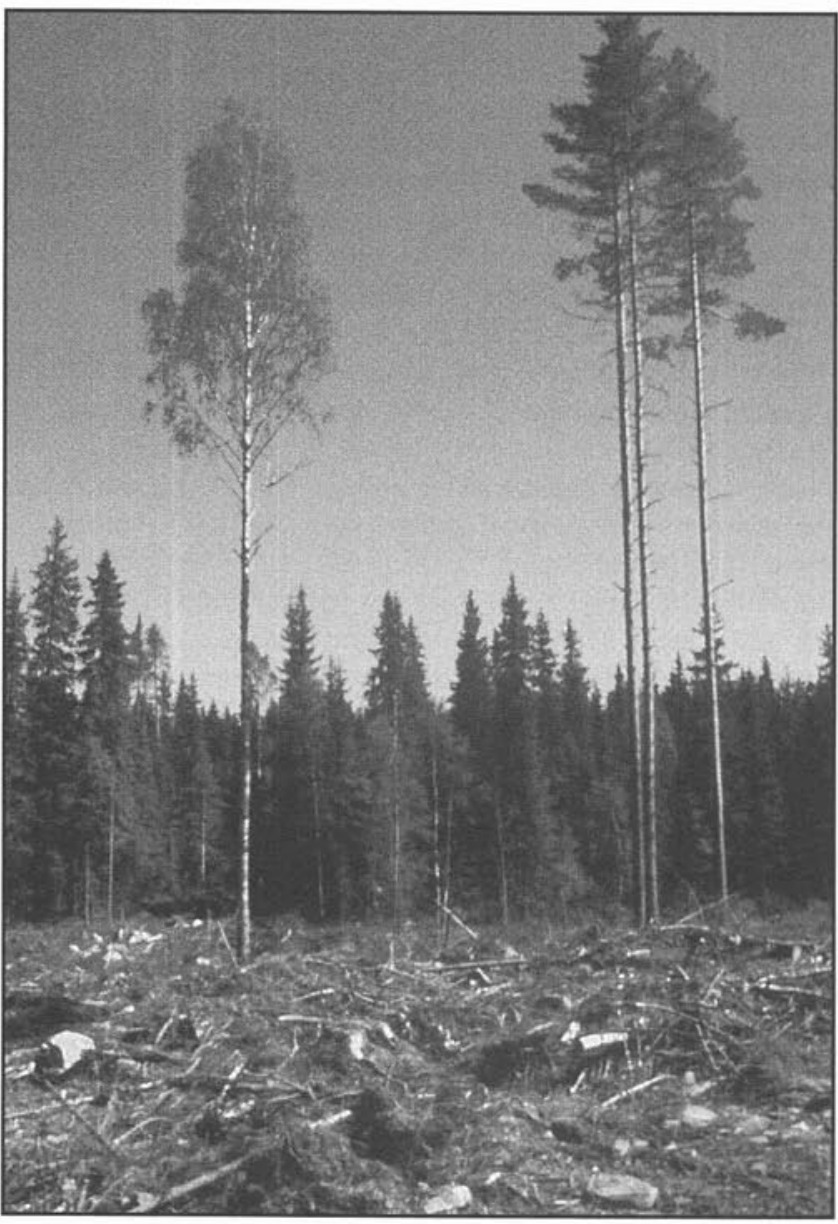

Fig. 2. Examples of wildlife leave trees in a cutblock in Sweden.

in spruce forests of southern Finland, beech forests of southern Germany, and in various forests of Finland, Russian Karelia, and Sweden.

\section{Impacts of Forestry on Biodiversity: Flora}

This session addressed the responses of plant species and communities to forest management practices and associated landscape changes such as habitat fragmentation, edge effect, and woody debris removal. Cases were presented from Sweden, Finland, Norway, Germany, Australia, and the United Kingdom.

\section{Impacts of Forestry on Biodiversity: Stands and Ecosystems}

These presentations provided examples of how forest management practices are manifest in biological changes at the stand and ecosystem scales. Included were studies from Sweden, Finland, France, Bavaria (Germany), and Australia. They addressed such aspects as vegetation responses to slash management and deer browsing; distribution of keystone ant species in relation to forest management; biodiversity changes in chestnut (Castanea sativa) groves and coppice stands; decaying wood dynamics and the conservation of saproxylic species; and other studies relating biodiversity to change at the stand and ecosystem levels.

\section{Processes, Structures, Composition}

The emphasis of these studies was in furthering understanding of biological processes and habitat relationships in forest ecosystems. The presentations addressed invertebrates in plantations of the United Kingdom; forest beetle communities in Nova Scotia (Canada); plant communities in oak woodlands of southern Spain and northern Morocco; soil ecology in taiga ecosystems of Russia; and bird/landscape dynamics in northeastern Finland.

\section{Management for Biodiversity}

This session featured pro-active approaches that strive to restore or maintain elements of biodiversity in managed forest systems. Three presentations from Australia varied from single species approaches (management for the swift parrot, Lathamus discolor); to an "umbrella species" approach featuring large forest owls and marsupials; to a landscape-scale fragmentation study. Other presentations discussed green tree retention and prescribed fire in Sweden, multi-ownership strategies in the Pacific Northwest (USA), selection harvest systems in Japan, "chaotic silviculture" strategies in the redwood forests of northern California, and habitat patch dynamics in relation to flying squirrel (Pteromys volans) population viability.

\section{Indicators, Monitoring, Planning}

In this session, planners and managers shared approaches for measuring biodiversity, detecting change, and assessing trends through time. Also included were modeling approaches to incorporate biodiversity and other values in forest planning, and proposed indicators for assessing ecological health. Speakers reported work underway in Germany, Finland, Sweden, the United States, and British Columbia.

\section{Case Studies}

The ecosystem management approaches of three Canadian forest companies (MacMillan Bloedel Ltd., Canadian Forest Products, Inc., Alberta Pacific Forest Industries, Inc.) were showcased in this session. Other case examples included regionallevel planning in the state forests of western Finland, and ecological landscape planning in Sweden.

\section{Field Excursion: South-central Sweden}

The greatest opportunities to view case examples occurred during the excursions. We begin by describing the three-day conference excursion to examine forest management and biodiversity conservation issues in south-central Sweden.

The first day began with an introduction to ecological landscape planning in the Vällen District, an area characterized by flat forested terrain, many boulders, and a long history of forestry to support the ironworks and forges that operated from the late 1600 s well into the last century. The forests here are relatively rich in deciduous species (aspen and oak) compared to most of Sweden. Despite its long history of use, the area still retains natural forest features, including populations of plants and animals that are seriously diminished elsewhere in Sweden. In 1993, a cooperative program was launched by the Uppland Foundation, a consortium of the local County Council and municipalities, and Korsnäs $\mathrm{AB}$, a forest company owning about $30 \%$ of the land in this area. Through ecological landscape planning, the partners are striving to manage the area in a way that preserves its significant natural values, including biological diversity. The management strategy includes maintenance of about $15 \%$ of the forest in deciduous trees; green tree retention; natural regeneration on $10 \%$ of the area, retention of 


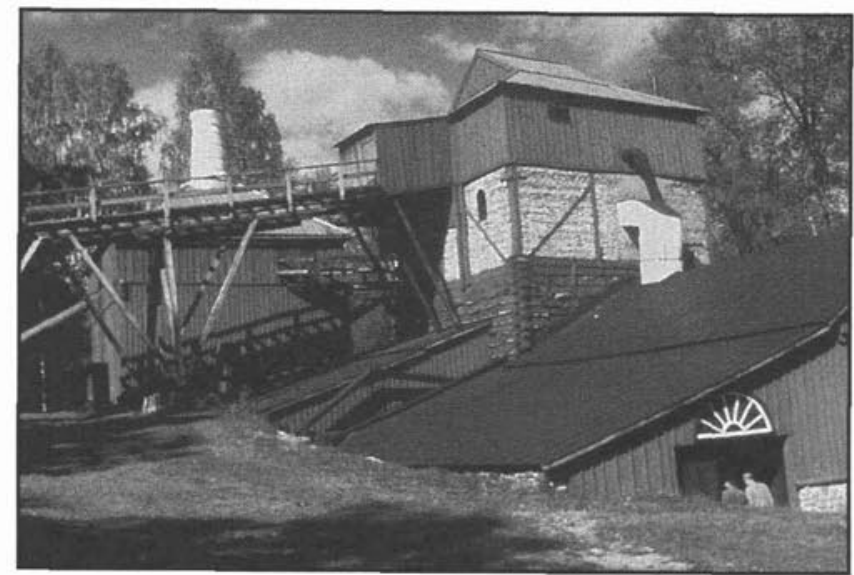

Fig. 3. Iron making and forests are closely linked in history. The Engelsbergs Ironworks Estate in the Norberg mining district of Sweden goes back to the 1680 's.

windthrown trees where possible, retention of snags and high stumps, and other practices. We also received a presentation on diversity and trends in the insect fauna of the area, with an emphasis on forest beetles.

The after-lunch stop featured 4 different topics. At station 1 , we learned about protected area planning and management in Sweden. There is a desire to increase the existing area of Sweden's preserves (about $3.7 \%$ of total land area) to a target of $10 \%$. Most existing preserves are in or near alpine areas. Of the total productive forest ( 23 million ha), only about $0.8 \%$ is protected. Significant developments in recent years include: an audit of protected area status by the International Union for the Conservation of Nature (IUCN); establishment in 1996 of Sweden's first Heritage Site for Nature and Culture; and designation of about 10,000 ha of productive forest land each year for protected area status.

Station 2 dealt with the natural disturbance ecology of Swedish forests. We examined a small prescribed burn that was done to investigate responses of forest plants and insects. Surprisingly, the burn had attracted fire-adapted insects, demonstrating their persistence in managed landscapes and suggesting the utility of prescribed fire as a biodiversity conservation tool.

Station 3 featured a discussion of forest certification in Sweden. An effort to develop national standards for forest certification is underway by the Swedish Forest Stewardship Council (FSC) Working Group, formed in February of 1996. Its purpose is to prepare proposals for submission to the Forest Stewardship Council, an independent, international organization based in Oaxaca, Mexico. The Working Group aims to include both small landowners and major companies in its certification scheme. Station 4 was a walking tour through a small wetland area, representative of sites that are protected as key woodland habitats.

The second day of the excursion began with a presentation by representatives of the Swedish Federation of Forest Owners. Family forests are a significant component of the forest sector in Sweden. About half the annual cut comes from family woodlots; and of that, about half goes through a forest owners' association. Seven such associations exist today, with a total membership of 90,000 . The primary objective of these forest owners is wood quality rather than maximization of quantity. Premium prices are obtained for lumber with high density of growth rings; hence, the faster growing trees are removed early in the rotation to favour the slower growing but more valuable individuals. During this stop, we learned that the Federation of Forest Owners had been in negotiations with the FSC but rejected that organization's forest certification scheme as a poor fit for family woodlot operations.

We also heard from representatives from the Mälardalen County Forestry Board, the local governmental authority for forest management. Following a brief history of Swedish forest policy and legislation, we learned that the roles of the County Forestry Boards include law enforcement, extension, inventory, subsidy assistance, and review/approval of plans submitted by private forest owners. Two national initiatives are underway on private, non-industrial lands: a survey of key habitats; and planning for a biotope reserve system. Key habitats and biotopes reserves are established through voluntary agreements between the County Boards of Forestry and the landowners; compensation is involved in cases where an owner has a disproportionately large number of key habitats such that protection significantly affects the existing uses of the land.

Unlike the family operations, the large forest companies generally strive for wood fiber quantity over quality. At one stop, we learned about the biodiversity conservation activities of Mellanskog, a cooperative society that includes more than half of all private forest owners in central Sweden. Through its two subsidiary companies, Mellanskog conducts comprehensive saw milling and timber processing activities and is developing the use of wood as fuel. Among its programs is the provision of monetary rewards to member landowners who develop an approved "Nature Conservation Document" to guide their forest management.

After lunch on day 2, we visited Grällsta Lantbruk $\mathrm{AB}$, a farm company located about $10 \mathrm{~km}$ south of the town of Sala. Owned by two families, the Carlssons and the Johanssons, the company combines farm production with small-scale forest management (done in winter, when farming slows down). Although small, farm/forest companies such as this can have access to the sawmills of Mellanskog and also participate in the Nature Conservation Document program of that organization.

Several stops during day 2 provided opportunity to view a variety of stand treatments including thinnings, shelterwoods, and seed tree cuttings. Also, we first heard the term "eternity trees" to describe green trees that are retained for biodiversity conservation purposes. The day ended with a visit to the Engelsbergs Ironworks Estate, situated in a district whose iron making traditions go back to the Middle Ages. This tour brought home several realities about the Swedish forests, including: the long history of occupation and resource extraction in the region; the inextricable linkages between forestry and iron making; and, the fact that Swedish forest landscapes today are an evolving legacy of that history.

On the third day, we traveled to Brynberget and climbed through the forest to a high ridge for an excellent view of the boreal landscape. Interpretive stations along the way featured lichens, decayrotting fungi, snags, down logs, rare mosses, and other special components of biodiversity. Discussions at the top focused on ecological planning at the landscape scale, defined as 5,000 to $25,000 \mathrm{ha}$. We obtained a forest history from Per Angelstam, one of Sweden's leaders in landscape ecology and ecological 


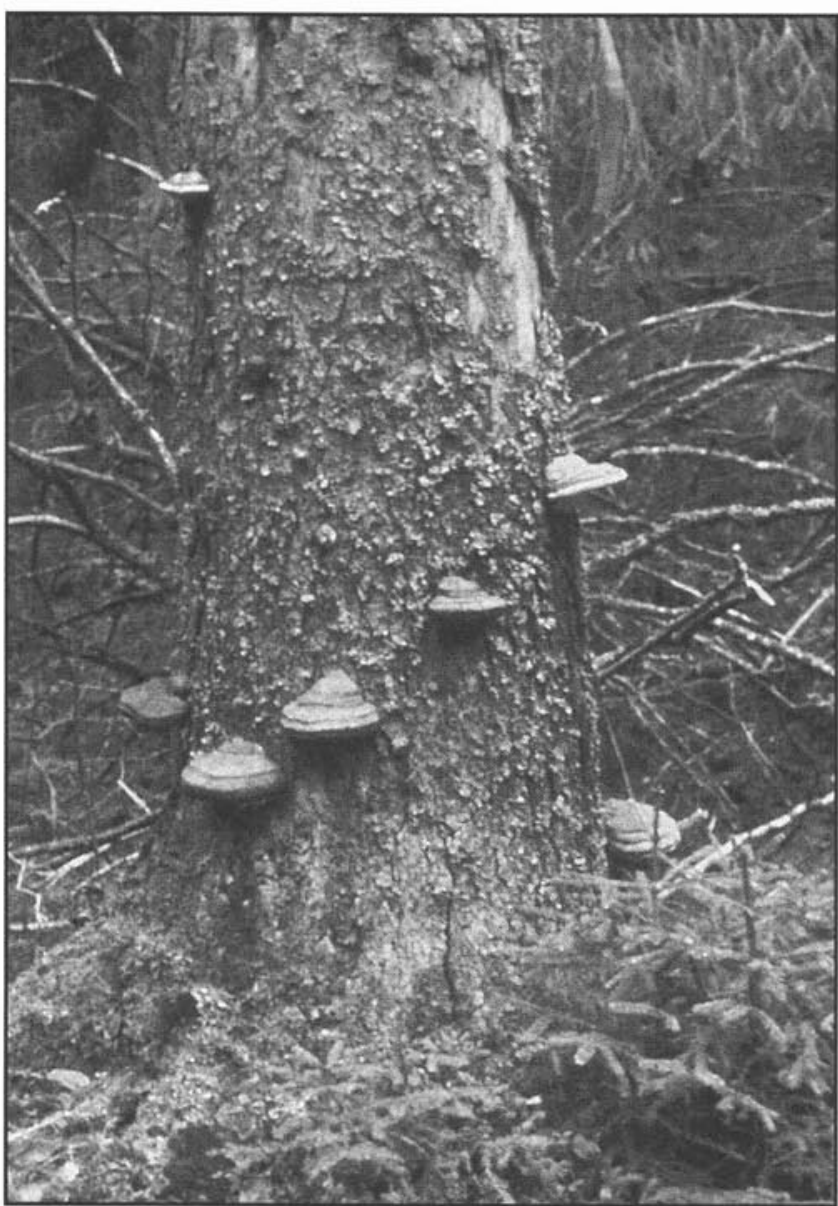

Fig. 4. Decay-rotting fungi and associated beetles are of high interest as elements of biodiversity. (Photo taken near Brynsberget, Sweden).

restoration (e.g., Angelstam and Majewski1996, Angelstam and Pettersson 1997). Conservation efforts at this scale are complicated by the pattern of land ownership. This is offset by the commitment and cooperation demonstrated by the companies, government, and non-government organizations.

While on the ridge, we received presentations by Stora Forest and Timber, one of Sweden's largest forest owners and a major supplier of wood in Europe. Representatives of this 1,000 year old company discussed their landscape-scale strategy for restoring and conserving biological diversity. Components include: zoning by land use intensity; designation of core areas (= key biotopes) for protection; restoration of core areas where needed; and establishment of landscape management goals. We discussed Stora's participation in the FSC process as a means to strengthen consumer confidence. Within the European market, the FSC is generally recognized as a credible and independent agent for product certification.

In the afternoon we departed for Malingsbo to view a field operation of AssiDomän $\mathrm{AB}$. The trees were cut to length and carried to the roadside by rubber-tired forwarders-a technique that minimized ground disturbance. This stop provided opportunity to discuss forest management, education, and training with both managers and field operators. We were impressed with the degree of responsibility delegated to the machine operators, including development and implementation of logging plans. Equally impressive was the conceptual

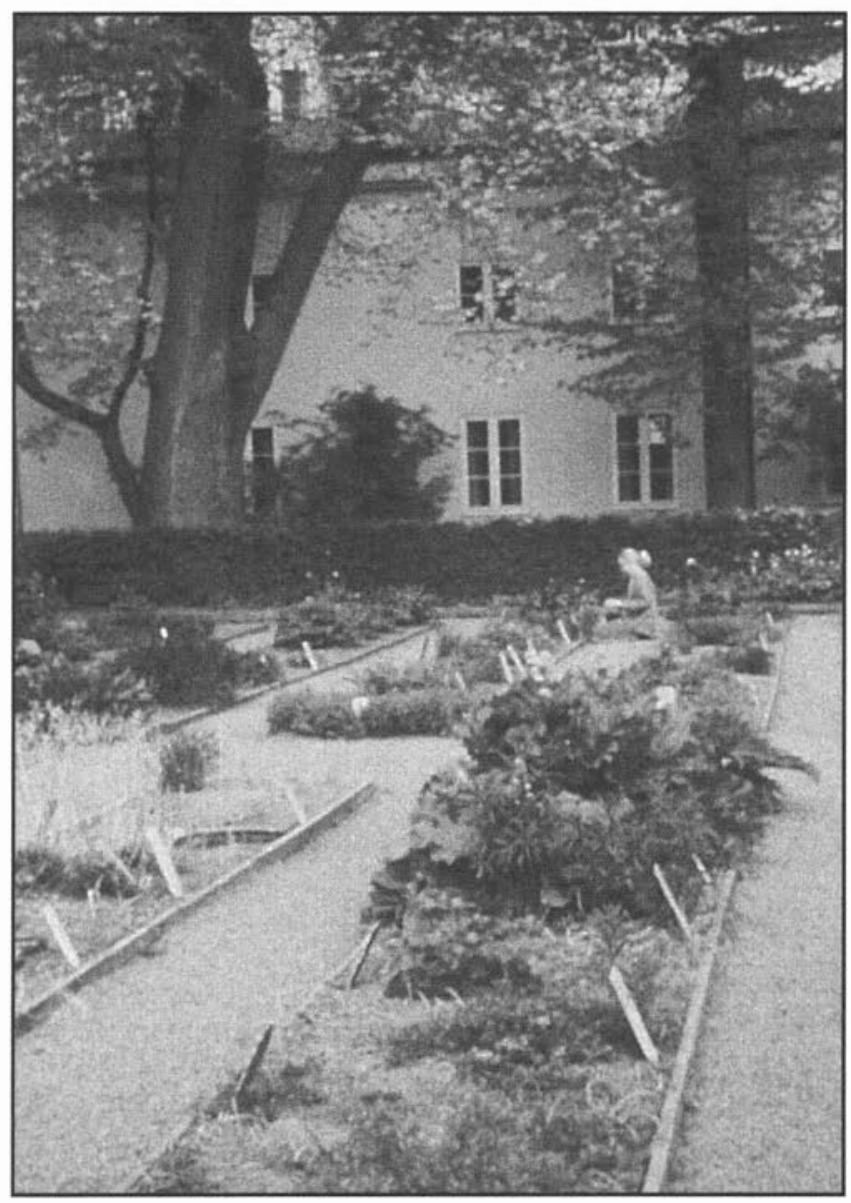

Fig. 5. Carl Linneas' botanical garden in Uppsala, Sweden.

and practical knowledge demonstrated by these operators with regard to ecological management. They described their approaches to green tree retention, wetland protection, and other practices as routine components of forest harvesting. These discussions revealed several interesting facts about the operators: they are highly valued members of their companies; they typically have decades of experience with the same company (and on the same lands); and they receive continuing training and education that includes new concepts of biodiversity conservation and management. Operators who are competent in a diversity of tasks-for example block layout, harvesting and regeneration, and spacing-are rewarded with higher salaries.

Additional discussions in AssiDomän's area included forestry education in Sweden, and the company's "Ecological Balance Sheet." The latter is an internal audit system, based on samples from 300 sites each year, by which AssiDomän field checks its conservation and resource protection practices. One purpose is to identify corrective actions and training needs. As well, this serves as preparation for the external certification process.

The field excursion ended with wrap-up comments by Swedish and American participants. An interesting perspective on forest certification was shared by Björn Hägglund of Stora Forest and Timber. He is skeptical of the view that companies who become certified will have a significant competitive edge in the forest products market. Rather, he suggests, 


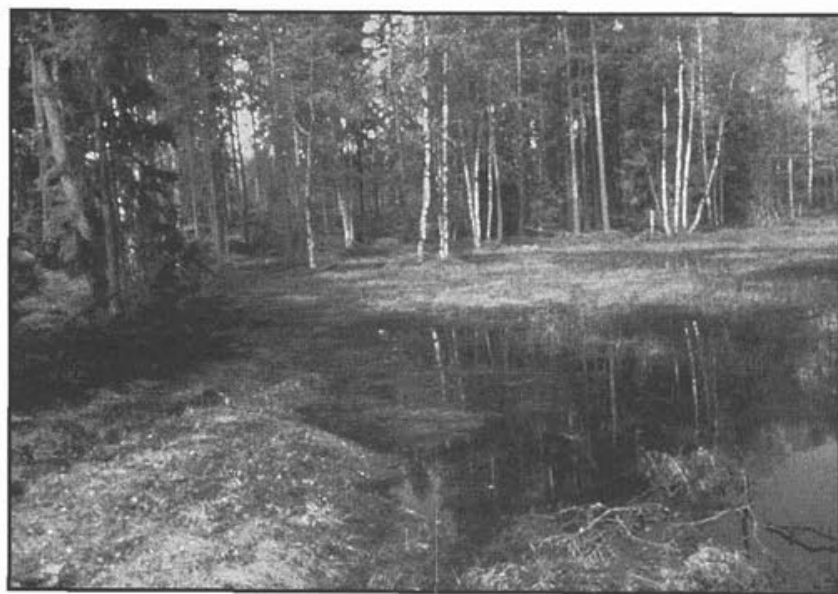

Fig. 6. Small wetland area typical of those that are protected as critical elements of biodiversity within managed forests in Sweden.

the real value of certification will be in demonstrating that wood is a sustainable and environmentally benign product compared to alternative materials used in manufacturing.

\section{Excursion: Finland and Russian Karelia}

After traveling from Stockholm to Helsinki by ferry, we began our forestry tour by visiting a gene reserve at Lapinjärvi and the Lusto Forest Museum at Punkaharju, and the Punkaharju Research Station of the Finnish Forest Research Institute. The next day featured a visit to the European Forest Institute in Joensuu (the organizers of the excursion), a view of cutting operations within an area managed by Enso, and an introduction to members of the Faculty of Forestry, University of Joensuu, and the Joensuu Research Station. Day 3 included a border crossing into Russian Karelia to view an unmanaged forest characterized by a heavy deciduous component, standing and down dead trees, and relatively high levels of biodiversity.

Our travels in Finland and Russian Karelia strengthened the impressions we had developed in Sweden. As in Sweden, forests are integral to the history, livelihoods, and cultural identities of the Finnish people. The condition of the forests today reveals a long history of occupation and use, and intensive management of timber resources in the current century. The conversion of the boreal forest to homogeneous conifer stands is more complete in Finland, although we were shown examples of mixed wood management, retention of aspen and birch trees, and other efforts to restore elements of biodiversity to forest landscapes. Other practices for ecological objectives include limitations on clearcut size; retention of wildlife trees, snags, and forest patches; and protection of wetlands within the managed forest.

Many scientists use the forests of Russian Karelia as a comparative basis for assessing biodiversity in Finland's managed forests (e.g., Kaila et al. 1994; Sitonen and Martikainen 1994). Even casual observation revealed striking contrasts. The presence of understory plants, snags, downed logs, wood decaying fungi, and associated insects enhanced the impressions of diminished biodiversity that we had experienced in the intensively managed forests of Sweden and Finland.

\section{Lasting Impressions}

Our experiences enlarged our understanding of forest management abroad, while offering new perspectives on forest management in western Canada. In this section, we summarize the impressions gained through our participation in the Conference on Biodiversity in Managed Forests.

\section{Silent Forests}

We were impressed with the extent to which boreal forest landscapes of Sweden and Finland have been converted to the efficient production of wood fibre, and how those changes are manifest in diminished biodiversity. The strongest impression occurred during the field excursions, in the form of silence during what should have been the peak season of wildlife activity in the boreal forest. We were keenly aware that, back in British Columbia, any visit to the forest would be lively with the sounds of birds and other wildlife. The conversion of Swedish and Finnish forests, while yielding great gains in production efficiency, has been costly in biological resources. While the effects were obvious to us, they have existed long enough that many Scandinavians are not aware of the reduction in species diversity nor of the simplification that has taken place in their forest ecosystems. We now understand why biologists in this part of the world devote so much attention to lichens, beetles, and decay rotting fungi; many other taxa are no longer represented in the managed forest. We appreciate, more than before, the richness of Canada's biological resources.

\section{What is Natural?}

In the North American concept of sustainable forest management, understanding the disturbance regimes, landscape patterns, composition, and structure of forest ecosystems is essential for designing management to maintain the ecological integrity and biological diversity of the forest. In Scandinavia, however, centuries of modification by people obscure the basic question of "what is natural?' Biodiversity conservation, while no less important in this region, requires a concept that fits the realities of Scandinavia's cultural and ecological landscapes.

\section{Maintaining Options}

We were impressed with the apparent commitment of forest owners and managers, especially in Sweden, to restore and maintain biodiversity to the managed forest. They are using many of the same stand and site-level practices as are used in western Canada: green tree and snag retention; increasing the deciduous component; management of coarse woody debris; and retention of habitat patches and buffers around wetland areas. In Scandinavia, however, most options exist only at the scale of sites and stands. The history of intensive management, as well as complex patterns of land ownership, provide few biodiversity planning and management options at the landscape scale. An important maxim of sustainable forest management is to keep options open for future generations. Our visit left us with increased awareness and appreciation for the full range of options, from stand levels to ecosystems, that are available for future management of the Canadian boreal forest.

\section{The Power of Cooperation}

Complicated patterns of land ownership create special challenges for the restoration and conservation of biological diversity in Scandinavian forests. Achievement of ecological goals and objectives is largely dependent upon voluntary actions, individual and corporate commitment, and a willingness to cooperate. We were impressed with how much 


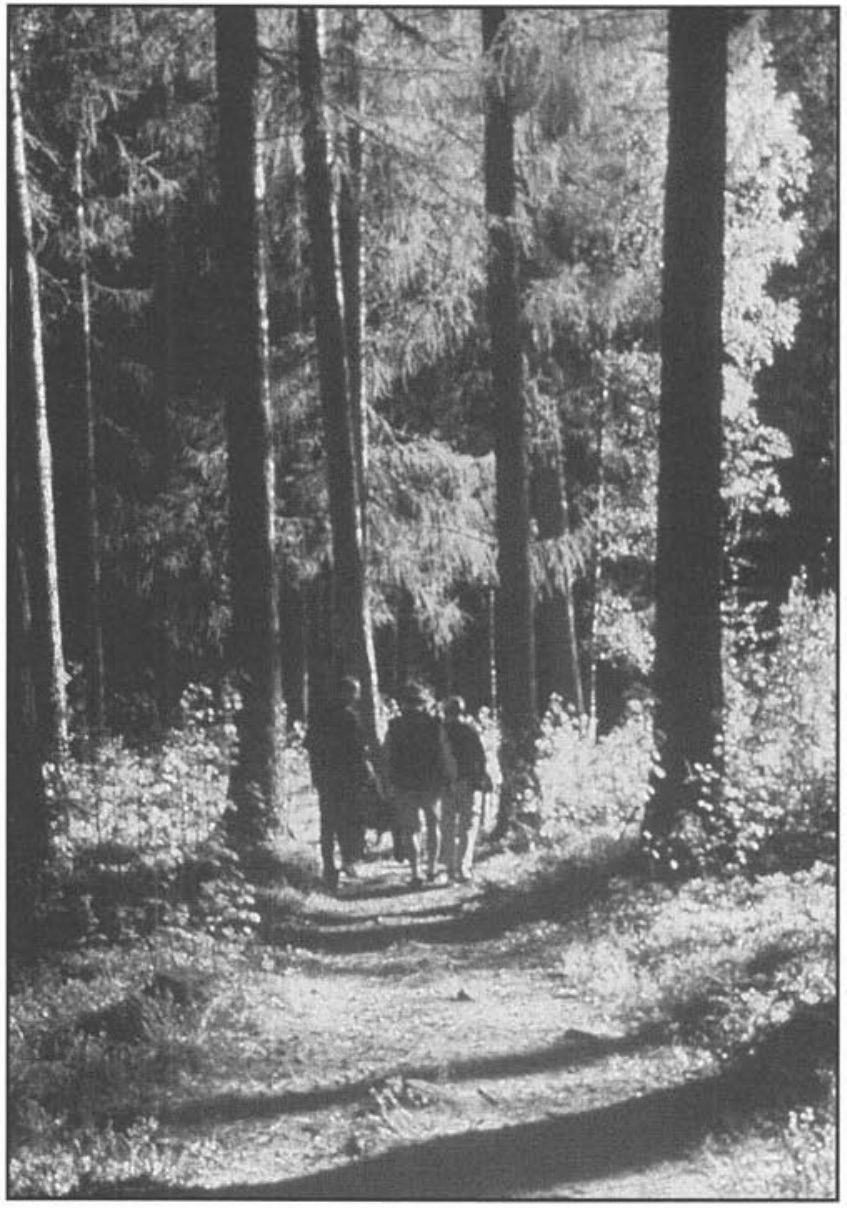

Fig. 7. Punkaharju Research Forest, Finland.

was being accomplished in Sweden and Finland on a voluntary basis. An excellent example is the Richer Forest initiative of the Swedish Board of Forestry, which has engaged 100,000 small forest owners in education and management activities to restore biodiversity in Swedish forests.

An important factor in this success is a culture that encourages cooperation. While there remains room for improvement, we did see examples of incentives, rewards, and compensation that promote a more equitable sharing of the costs and benefits of biodiversity conservation. We thought about our home province of British Columbia, where relationships between forest industry, government agencies, First Nations, and other parties are often adversarial. We imagined what it would take to turn this around, and what biodiversity conservation gains might be possible in an environment that more strongly encouraged voluntary action, commitment, and cooperation.

\section{Stewardship Teams}

We took note of the way in which employees of the forest companies, from the machine operators up to the executives, seemed to function as integrated teams. The experience and knowledge of long-time employees is highly valued, and there is considerable delegation of responsibility to the people on the ground. Field operators are provided with continuing training and education to meet the new demands in forest management, including practices aimed at biodiversity conservation. They are entrusted to think carefully about their work so that good

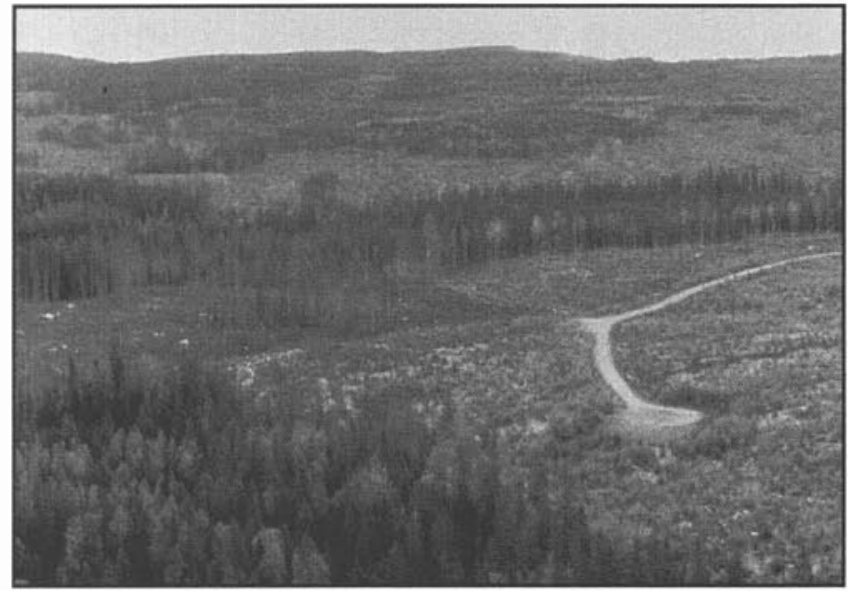

Fig. 8. View of the Swedish boreal landscape (taken near Brynberget).

judgements will be made on the ground. In winter there are mandatory, week-long study circles to ensure that workers keep abreast of new developments, including concepts and practices for biodiversity conservation. Several companies have self-audit systems to ensure that everyone's efforts are contributing toward shared environmental goals.

The impression we gained was of people working together for long periods of time, on the same areas of land, for goals and objectives that were well understood by all. To use a simple metaphor, the choir has practiced together for years, and everybody is singing from the same sheet of music. This cooperative approach forced us to think critically about forest management in the environments that we are most familiar with. In western Canada, most forest lands are owned by the public, but are managed by the companies who have tenure rights to the timber resources. Typically, a company hires private consulting foresters to develop plans and prescriptions, while government personnel are responsible for review and approval of those plans. Cruising and cutblock layout are typically done under a separate contract, as is the actual harvesting operation. After harvesting is completed, companies enter into yet more contracts for reforestation and stand tending. Many individuals are involved in forest management, but each receives only a glimpse of the total management picture for an area. We had to wonder: what are the prospects for longterm stewardship in such a system? The contrast with the Scandinavian situation, where individuals learn the details of an area and are alert to even subtle changes, could not be ignored.

\section{The Art of the Field Excursion}

Based on our experiences, we must conclude that Scandinavians are masters in the art of the field excursion. Every detail was planned and executed in remarkable detail, from the well illustrated field presentations, to elegant coffee breaks in the woods, to the excellent meals and accommodation at every stop. Our only reservation was wondering how we might approach these standards in future tours in Canadian forests, especially when Scandinavians are among our guests.

\section{New Beginnings}

Among the new developments we learned about is Sweden's new Forestry Act, which went into force on January 1, 1994. The opening provision states that "The forest is a National resource. It shall be managed in such a way as to provide a valuable yield 
and at the same time preserve biodiversity" (National Board of Forestry 1994). Although lacking in specific regulations, the new act clearly gives equal weight to production goals and protection of the environment. Just how extensive the changes will be remains to be seen. However, Sweden's tradition of cooperation provides fertile ground for actions aimed at the restoration of biologically impoverished landscapes.

\section{References}

Angelstam, P. and P. Majewski. 1996. Reference landscapes for improved forest landscape management in eastern and western Europe. pp. 111-123 In Proceedings of the International Workshop on Assessment of Biodiversity for Improved Forest management. Backmann, P. et al. (eds.). European Forest Institute Proceedings No. 6 , Joensuu, Finland.

Angelstam, P. and B. Pettersson. 1997. Principles of present Swedish forest biodiversity management. Ecological Bulletins (Sweden): 46: 191-203.

Finnish Forestry Association, undated. Finland: the country of forests. Finnish Forestry Association, Helsinki.

Gustafsson, L. 1996. Biodiversity assessments in Swedish forestry based on data on red-listed species. pp. 143-148 In Proceedings of the International Workshop on Assessment of Biodiversity for Improved Forest management. Backmann, P. et al. (eds.). European Forest Institute Proceedings No. 6, Joensuu, Finland.
Kaila, L., P. Martikainen, P. Punttila, and E. Yakovlev. 1994. Saproxylic beetles (Coleoptera) on dead birch trunks decayed by different polypore species. Ann. Zool. Fennici 31: 97-107.

Kessler, W. 1996. Ecosystems and people in temperate and boreal forests. Forestry Chronicle 72: 576-579.

Kolm, K.A. and J.F. Franklin. 1996. Creating a forestry for the 21 st century: the science of ecosystem management. Island Press, Washington, DC. $475 \mathrm{pp}$.

National Board of Forestry. 1994. The Forest Act. National Board of Forestry, Jonkoping, Sweden.

National Board of Forestry. 1996. The Swedish forest: a compilation of facts on forestry and the forest industries in Sweden. National Board of Forestry, Jonkoping, Sweden..

Norton, T. 1995. Editor special edition: Forest Ecology and Management 85. Elsevier Science, Netherlands.

Sitonen, J. and P. Martikainen. 1994. Occurrence of rare and threatened insects living on decaying Populus tremula: A comparison between Finnish and Russian Karelia. Scand. J. For. Res. 9: 185-191. 